Studia nad Autorytaryzmem i Totalitaryzmem 42, nr 2

Wrocław 2020

https://doi.org/10.19195/2300-7249.42.2.6

\author{
WITOLD MAŁECKI \\ ORCID: 0000-0002-8819-0317 \\ Uniwersytet Wrocławski \\ witold.malecki@uwr.edu.pl
}

\title{
Prawo gospodarczo-administracyjne w koncepcji „dwóch sektorów” Piotra Iwanowicza Stuczki
}

\begin{abstract}
Abstrakt: Koncepcja „dwóch sektorów” P.I. Stuczki, sformułowana na przełomie lat dwudziestych i trzydziestych ubiegłego stulecia, we współczesnej literaturze ujmowana jest powszechnie jako pierwsza teoretyczna koncepcja wyodrębniania prawa gospodarczego w nauce radzieckiej. W licznych opracowaniach odwołujących się do koncepcji „dwóch sektorów” prawo gospodarcze (a właściwie prawo gospodarczo-administracyjne) jest przedstawiane jako gałąź przeciwstawiana prawu cywilnemu - wskazuje się, że prawo gospodarczo-administracyjne obejmowało regulację socjalistycznego sektora gospodarki, podczas gdy prawo cywilne normowało funkcjonowanie sektora prywatnego. W rezultacie rywalizacji obu sektorów sektor socjalistyczny miał wyprzeć sektor prywatny, a w konsekwencji prawo gospodarczo-administracyjne miało zająć miejsce prawa cywilnego. Przedstawiana w tym kształcie powierzchowna charakterystyka koncepcji „dwóch sektorów” nie daje jednak pełnego i właściwego obrazu prawa gospodarczego (gospodarczo-administracyjnego) w ujęciu P.I. Stuczki.

W artykule zostało dowiedzione, że P.I. Stuczka postrzegał prawo gospodarczo-administracyjne w aspekcie dynamicznym — jako pożądany kierunek przyszłego rozwoju regulacji normujących funkcjonowanie socjalistycznego sektora gospodarki, wobec czego prawo gospodarczo-administracyjne nie było przez niego uznawane za gałąź równorzędną prawu cywilnemu. Prawo gospodarczo-administracyjne było rozumiane przez P.I. Stuczkę jako teoretyczna koncepcja modelowego obrazu pewnego zbioru unormowań, której przyszłe odzwierciedlenie w sferze prawa pozytywnego P.I. Stuczka uznawał za pożądane i celowe. Odzwierciedlenie to powinno przybrać postać kodeksu gospodarczo-administracyjnego, który zawierałby normy całościowo regulujące funkcjonowanie socjalistycznego sektora gospodarki radzieckiej. Koncepcja prawa gospodarczo-administracyjnego nie była opisem obowiązujących ówcześnie regulacji prawnych — jakkolwiek P.I. Stuczka zwracał uwagę na wyodrębnienie się w systemie prawa grupy „norm gospodarczo-administracyjnych”, normy te de lege lata nie formowały samodzielnej gałęzi prawa. Koncepcji prawa gospodarczo-administracyjnego należy zatem przypisać charakter postulatywny, nie zaś deskryptywny.

W artykule wskazano również, że wyróżnienie prawa gospodarczo-administracyjnego ukształtowało się na gruncie krytycznego postrzegania przez P.I. Stuczkę szerokiego zakresu regulacji i stosowania kodeksu cywilnego Rosyjskiej Federacyjnej Socjalistycznej Republiki Radzieckiej przyjętego w 1922 roku. Zamysł kodeksu cywilnego jako aktu prawnego całościowo regulującego
\end{abstract}


ogół stosunków majątkowych i gospodarczych był zdaniem P.I. Stuczki nieakceptowalny w państwie socjalistycznym i nie odpowiadał realiom funkcjonowania społeczeństwa oraz gospodarki radzieckiej. Sferą regulacji prawnej, której objęcie oddziaływaniem kodeksu cywilnego przedstawiało się dla P.I. Stuczki jako szczególnie wątpliwe, było funkcjonowanie socjalistycznego sektora gospodarki, to jest stosunków między tworzącymi ten sektor przedsiębiorstwami państwowymi. Mając na względzie zasadnicze różnice w materii stosunków kształtujących się w sektorze socjalistycznym (bazujących na planowości) i sektorze prywatnym (bazujących na anarchii), P.I. Stuczka wskazywał, że różnice te powinny znajdować odzwierciedlenie także w formie prawnej regulacji funkcjonowania obu sektorów. Dla regulacji funkcjonowania zorganizowanego (ustrukturyzowanego) sektora socjalistycznego nieadekwatne były regulacje cywilnoprawne, oparte na paradygmacie stosunków między podmiotami samodzielnymi i autonomicznymi, przybierających charakter horyzontalny. Prawo normujące sektor socjalistyczny winno mieć charakter prawa gospodarczo-administracyjnego, którego administracyjne znamię odnosiłoby się do aktywnej roli organów państwowych w dziedzinie zarządzania socjalistycznym sektorem gospodarki.

Słowa kluczowe: koncepcja „dwóch sektorów”, Piotr Stuczka, prawo gospodarcze, prawo gospodarczo-administracyjne, prawo radzieckie.

\title{
ECONOMIC-ADMINISTRATIVE LAW IN PYOTR IVANOVICH STUCHKA'S "TWO SECTORS" THEORY
}

\begin{abstract}
P.I. Stuchka's "two sectors" theory, formulated at the turn of the 1920s and 1930s, is widely recognized in contemporary literature as the first theoretical concept of distinguishing economic law in Soviet jurisprudence. In numerous studies referring to the concept of "two sectors", economic law (or rather - economic-administrative law) is presented as a branch opposed to civil law - it is indicated that economic-administrative law included the regulation of the socialist sector of the economy, while civil law regulated the functioning of the private sector. As a result of the rivalry between the two sectors, the socialist sector was to oust the private sector, and as a consequence economic-administrative law was to take the place of civil law. However, the superficial characteristics of the "two sectors" concept presented in the above shape do not give a full and proper picture of economic (economic-administrative) law in terms of P.I. Stuchka.

It was proved in the article that P.I. Stuchka perceived economic-administrative law in a dynamic aspect - as a desirable direction for the future development of norms regulating the functioning of the socialist sector of the economy, therefore economic-administrative law was not considered by him as an equivalent branch to civil law. Economic-administrative law was seen by P.I. Stuchka as the theoretical concept of a model image of a certain set of regulations, whose future reflection in the sphere of positive law he considered desirable. This reflection should take the form of an economic-administrative code which would contain norms that comprehensively regulate the functioning of the socialist sector of the Soviet economy. The concept of economic-administrative law was not a description of the legal regulations in force at that time - although P.I. Stuchka pointed out the emergence of "economic-administrative norms" in the system of law, these norms did not form an independent branch of law. The concept of economic and administrative law should therefore be assigned a postulative rather than descriptive character.

The article also indicates that the distinction of economic-administrative law was based on P.I. Stuchka's critical perception of the wide scope of regulation and application of the Civil Code of the Russian Soviet Federative Socialist Republic adopted in 1922.The idea of the Civil Code as a legal act regulating comprehensively all property and economic relations was, according to
\end{abstract}


P.I. Stuchka, unacceptable in a socialist state and did not correspond to the realities of the functioning of the Soviet society and economy. The sphere of legal regulation, whose coverage by the Civil Code seemed particularly doubtful to P.I. Stuchka, was the functioning of the socialist sector of the economy, i.e. relations between the state enterprises forming this sector. Bearing in mind the fundamental differences in the matter of relations formed in the socialist sector (based on planning) and the private sector (based on anarchy), P.I. Stuchka pointed out that these differences should also be reflected in the legal form of regulation of the functioning of both sectors. For the regulation of the functioning of the organized (structured) socialist sector, civil law regulations based on the paradigm of relations between independent and autonomous entities assuming a horizontal character were inadequate. The law regulating the socialist sector should have the character of economic-administrative law, the administrative mark of which would refer to the active role of state organs in the field of management of the socialist sector of the economy.

Keywords: „two sectors” theory, Pyotr Stuchka, economic law, economic-administrative law, Soviet law.

\section{I}

Zagadnienie struktury poziomej systemu prawa było na przestrzeni lat przedmiotem ożywionego zainteresowania nauki radzieckiej. Uczeni radzieccy, przyjmując stanowisko o obiektywnym zdeterminowaniu struktury poziomej systemu prawa, uznawali, że rolą nauki prawa jest odkrywanie podziału systemu prawa na samoistnie kształtujące się gałęzie, regulujące obiektywnie odróżniające się kategorie stosunków społecznych ${ }^{1}$. W 1939 roku prokurator generalny ZSRR A.J. Wyszyński, podkreślając doniosłość badań nad systemem prawa, wskazywał, że właściwie ustrukturyzowany system prawa stanowi „klucz do poznania natury, zasad i właściwości prawa w ogólności oraz każdej ze szczegółowych instytucji prawa"2. Imperatyw precyzyjnego określenia struktury poziomej systemu prawa wymagał sformułowania ścisłych kryteriów wyróżnienia i rozgraniczenia poszczególnych gałęzi — w rezultacie dyskusji prowadzonej w nauce radzieckiej w latach 1956-1958 (zapoczątkowanej przyjęciem na XX Zjeździe KPZR w 1956 roku stanowisk o rozmijaniu się teoretycznych badań nad prawem z potrzebami praktyki oraz konieczności podjęcia prac kodyfikacyjnych nad poszczególnymi

${ }^{1}$ Zob. O.S. Ioffe, Izbrannye trudy po graždanskomu pravu. Iz istorii civilističeskoj mysli. Graždanskoe pravootnošenie. Kritika teorii , hozâjstvennogo prava”, Moskwa 2000, s. 707. W nauce polskiej, również przed 1989 rokiem, przeważało stanowisko o subiektywnej determinacji struktury poziomej systemu prawa — oddają je słowa $\mathrm{H}$. Rota: „nie istnieją jakieś wymierne — ilościowe czy jakościowe przesłanki, z góry przesądzające o tym, że jakaś grupa przepisów prawnych powinna ze względów obiektywnych znaleźć się poza danym działem prawa i ukonstytuować nowy dział" idem, Jedność i podziały systemu prawa socjalistycznego, Wrocław 1971, s. 71.

2 A.Â. Vyšinskij, XVIII s"ezd VKP(b) i zadači nauki socialističeskogo prava, „Sovetskoe gosudarstvo i prawo" 1939 , nr 3, s. 23. Tłum. W.M. 
gałęziami prawa radzieckiego) za kryteria wyodrębniania gałęzi prawa uznano przedmiot regulacji i metodę regulacji ${ }^{3}$.

W dyskusjach nad katalogiem gałęzi prawa radzieckiego, prowadzonych nie tylko w latach 1956-19584, szczególne kontrowersje wywoływała kwestia zasadności wyróżniania jako samodzielnej gałęzi prawa gospodarczego. Kwestia ta odznaczała się istotnym znaczeniem w perspektywie teoretycznej i praktycznej - prawo gospodarcze miało regulować stosunki kształtujące się $\mathrm{w}$ sferze wytwórczości towarów, stanowiącej fundament funkcjonowania państwa socjalistycznego opartego na dyktaturze proletariatu. W płaszczyźnie teoretycznej analiza problemu wyodrębniania prawa gospodarczego, a w szczególności oddzielenia go od prawa cywilnego, wymagała podjęcia rozważań nad podstawowymi założeniami i kryteriami określania struktury poziomej systemu prawa — jak wskazywał S. Włodyka w 1964 roku, problem prawa gospodarczego — zarówno w nauce burżuazyjnej, jak i w nauce państw socjalistycznych — wywołuje „namiętne spory, dotyczące nie tylko możliwości i celowości wydzielenia »prawa gospodarczego«, ale sięgające często do samych podstaw funkcjonowania systemu prawnego i jego roli jako regulatora stosunków społecznych"5.

$\mathrm{W}$ ciągu lat $\mathrm{w}$ nauce radzieckiej ${ }^{6}$ ukształtowała się znaczna liczba stanowisk teoretycznych dotyczących tożsamości prawa gospodarczego i jego miejsca w systemie prawa. Bodaj w każdym opracowaniu odnoszącym się do zagadnienia historycznego kształtowania się koncepcji postrzegania prawa gospodarczego w nauce radzieckiej jako pierwsza przedstawiana jest koncepcja „dwóch sektorów" (dvuhsektornaâ teoriâ) autorstwa P.I. Stuczki, sformułowana na przełomie lat dwudziestych i trzydziestych ubiegłego stulecia. W opracowaniach tych, w ramach charakterystyki koncepcji „,dwóch sektorów”, przyjęło się ujmować prawo gospodarcze (a właściwie prawo gospodarczo-administracyjne) jako gałąź przeciwstawianą prawu cywilnemu — wskazuje się bowiem, że prawo gospodarczo-administracyjne obejmowało regulację socjalistycznego sektora gospodarki, podczas gdy prawo cywilne normowało funkcjonowanie sektora prywatnego. W rezultacie

3 Zob. m.in. V.S. Tadevosân, Nekotorye voprosy sistemy sovetskogo prava, ,Sovetskoe gosudarstvo i pravo" 1956, nr 9, s. 99-108; M.D. Šargorodskij, O.S. Ioffe, O sisteme sovetskogo prava, „Sovetskoe gosudarstvo i prawo” 1957, nr 6, s. 101-110; I.V. Pavlov, O sisteme sovetskogo socialističeskogo prava, „Sovetskoe gosudarstvo i prawo” 1958, nr 11, s. 3-18.

4 Zob. W. Małecki, Dyskusja nad koncepcja prawa gospodarczego w nauce radzieckiej $w$ latach 1956-1958, „Krakowskie Studia z Historii Państwa i Prawa” 2016, nr 9, z. 3, s. 367-378.

5 S. Włodyka, Problem „prawa gospodarczego”, „Studia Cywilistyczne” 5, 1964, s. 68.

${ }^{6}$ Po rozpadzie Związku Radzieckiego studia teoretyczne nad prawem gospodarczym kontynuowane są przede wszystkim w nauce rosyjskiej i ukraińskiej, przy czym nauka rosyjska posługuje się obecnie pojęciem „prawa przedsiębiorczego" (predprinimatel'skoe pravo). W nauce ukraińskiej najwybitniejszym teoretykiem prawa gospodarczego był zmarły w 2018 roku W.K. Mamutow czołowy przedstawiciel tak zwanej donieckiej szkoły prawa gospodarczego. W.K. Mamutow postrzegał prawo gospodarcze jako samodzielną i odrębną gałąź prawa, odznaczającą się między innymi swoistą metodą regulacji - zob. idem, Hozâjstvennoe pravo (Ukrainy), Kijów 2002, s. 29-31. 
rywalizacji obu sektorów sektor socjalistyczny miał wyprzeć (wyeliminować) sektor prywatny, a w konsekwencji prawo gospodarczo-administracyjne miało zająć miejsce prawa cywilnego. Przedstawiana w tym kształcie powierzchowna charakterystyka koncepcji „dwóch sektorów” nie daje jednak pełnego i właściwego obrazu prawa gospodarczego (gospodarczo-administracyjnego) w ujęciu P.I. Stuczki. W niniejszym artykule zostanie dowiedzione, że P.I. Stuczka postrzegał prawo gospodarczo-administracyjne w aspekcie dynamicznym - jako pożądany kierunek przyszłego rozwoju regulacji normujących funkcjonowanie socjalistycznego sektora gospodarki, wobec czego prawo gospodarczo-administracyjne nie było przez niego uznawane za gałąź równorzędną prawu cywilnemu. Zostanie także wskazane, że wyróżnienie prawa gospodarczo-administracyjnego ukształtowało się na gruncie krytycznego postrzegania przez P.I. Stuczkę zakresu regulacji i stosowania kodeksu cywilnego Rosyjskiej Federacyjnej Socjalistycznej Republiki Radzieckiej (RFSRR) przyjętego w 1922 roku.

\section{II}

Piotr Iwanowicz Stuczka należał do czołowych prawników radzieckich okresu porewolucyjnego. Urodził się w 1865 roku w rodzinie chłopskiej na Łotwie. Ukończył prawo na Uniwersytecie Petersburskim, po czym wykonywał zawód adwokata, działając także w Socjaldemokratycznej Robotniczej Partii Rosji. Uczestniczył w rewolucji październikowej, po której pełnił liczne funkcje w kształtujących się strukturach władzy radzieckiej ${ }^{7}$ — był między innymi ludowym komisarzem sprawiedliwości RFSRR, a w 1923 roku jako pierwszy objął stanowisko przewodniczącego Sądu Najwyższego RFSRR, które piastował do śmierci w 1932 roku. Działał też w dziedzinie nauki prawa - był autorem licznych publikacji dotyczących podstawowych problemów teoretycznych prawa radzieckiego, sprawował funkcję głównego redaktora pierwszej radzieckiej Encyklopedii państwa i prawa (opracowanej w latach 1925-1927).

Przedmiotem szczególnego zainteresowania naukowego P.I. Stuczki stało się prawo cywilne - do jego najważniejszych dzieł należy trzytomowy Kurs radzieckiego prawa cywilnego 9 , wydawany w latach 1927-1931, w zasadniczej części poświęcony analizie unormowań kodeksu cywilnego RFSRR z 1922 roku. Przyjęcie

${ }^{7}$ A. Bosiacki zaznacza, że „bezpośrednio po rewolucji P.I. Stuczka wyrósł na najwybitniejszego eksperta prawnego nowej władzy" - idem, Utopia, władza, prawo. Doktryna i koncepcje prawne ,bolszewickiej” Rosji 1917-1921, Warszawa 1999, s. 118.

8 Stučka Petr Ivanovič, [w:] A.G. Zvâgincev, Û.G. Orlov, Neizvestnaâ Femida. Dokumenty, sobytiâ, lûdi, Moskwa 2003, s. 260-261.

9 P.I. Stučka, Kurs sovetskogo graždanskogo prava, t. 1. Vvedenie v teoriû graždanskogo prava, Moskwa 1927; t. 2. Obŝâa čast' graždanskogo prava, Moskwa 1929; t. 3. Osobennaâ čast' graždanskogo prava, Moskwa-Leningrad 1931. 
kodeksu było związane z wprowadzeniem w 1921 roku w związku z decyzją X Zjazdu Rosyjskiej Partii Komunistycznej (bolszewików) Nowej Polityki Ekonomicznej, w ramach której dopuszczono funkcjonowanie małych przedsiębiorstw prywatnych, monopol zaś państwa utrzymano w priorytetowych dziedzinach gospodarki, takich jak przemysł ciężki, bankowość, transport i handel zagraniczny ${ }^{10}$. W warunkach ustroju gospodarczego wyznaczonego przez Nową Politykę Ekonomiczną, obejmującego elementy właściwe gospodarce rynkowej, uznano, że gałęzią prawa, której normy będą w największym stopniu adekwatne do objęcia dziedziny gospodarki regulacją prawną, powinno stać się prawo cywilne — podobnie jak na gruncie przedrewolucyjnej gospodarki kapitalistycznej ${ }^{11}$.

Kodeks cywilny RFSRR z 1922 roku, określający kształt stosunków majątkowych i gospodarczych w sposób odpowiadający potrzebom wynikającym z funkcjonowania w gospodarce radzieckiej sektora prywatnego, w dużym stopniu nawiązywał do romanistycznego dorobku zachodniej cywilistyki ${ }^{12}$. Okoliczność ta została negatywnie przyjęta przez część radzieckich uczonych, którzy przypuszczali, że po rewolucji październikowej prywatny obrót gospodarczy i regulujące go ,tradycyjne” prawo cywilne odejdą do przeszłości - czołowy teoretyk prawa okresu porewolucyjnego A.G. Gojchbarg ${ }^{13}$ wspominał, że w 1920 roku podczas dyskusji nad potrzebą kodyfikacji prawa cywilnego oświadczył, że „dążenie do kodyfikacji prawa cywilnego to dążenie do kodyfikacji ziemi usuwającej się spod nóg"14. Po przyjęciu kodeksu cywilnego RFSRR szczególnie krytyczne stanowisko wobec niego wyrażała grupa uczonych zebranych wokół czasopisma „Prawo i Życie” („Pravo i žizn””), którzy wskazywali, że uchwalenie kodeksu prowadzi do hamowania dorobku i dynamiki rewolucji przez sprzyjanie powrotowi dotychczasowego burżuazyjnego porządku gospodarczego i prawnego ${ }^{15}$. Wśród uczonych krytycznych wobec kodeksu cywilnego z 1922 roku można wskazać W.N. Szretera, który charakteryzował kodeks jako „bezbarwne instrumentarium” pozbawione „wewnętrznego społecznego ukierunkowania”"16.

Negatywną ocenę kodeksu cywilnego RFSRR z 1922 roku prezentował także P.I. Stuczka. Jakkolwiek początkowo, w wydanej w 1924 roku monografii

10 D. Marples, Historia ZSRR, Wrocław 2006, s. 100.

11 S. Włodyka, op. cit., s. 83.

12 O genezie kodeksu cywilnego RFSRR z 1922 roku zob. A. Lityński, Prawo Rosji i ZSRR 1917-1991, czyli historia wszechzwiązkowego komunistycznego prawa (bolszewików). Krótki kurs, Warszawa 2017, s. 236-239.

13 Warto zaznaczyć, że początkowo krytyczny wobec kodyfikacji prawa cywilnego A.G. Gojchbarg stał się niedługo później wiodącym twórcą kodeksu cywilnego RFSRR z 1922 roku — A. Bosiacki, op. cit., s. 325.

14 A.G. Gojhbarg, Hozâjstvennoe pravo RSFSR, t. 1. Graždanskij kodeks, Moskwa-Leningrad 1923, s. 5.

15 Za: L.Â. Gincburg, K voprosu o hozâjstvennom prave, „Sovetskoe gosudarstvo i prawo” 1956, nr 8, s. 85.

16 V.N. Šreter, Sovetskoe hozâjstvennoe prawo, Moskwa-Leningrad 1928, s. 34. 
Państwo klasowe i prawo cywilne, zwracał on uwagę na okoliczność, że kodeks cywilny w swoich podstawowych założeniach opiera się na władzy państwowej proletariatu i państwowej własności socjalistycznej, to jednak już trzy lata później jego stanowisko co do oceny ogólnego charakteru kodeksu się zmieniło ${ }^{17}$. W tekstach opublikowanych w 1927 roku P.I. Stuczka wyraźnie podkreślał burżuazyjny rodowód unormowań kodeksu cywilnego, zaznaczając, że kodeks cywilny „,nie jest niczym innym niż formą burżuazyjnego prawa cywilnego, odzwierciedlającą ogólny wzór prawa rzymskiego stworzony około dwóch tysięcy lat temu" "18, a także „prawie w całości stanowi zapożyczenie z kodeksów burżuazyjnych, z dodaniem tylko nieznacznej liczby artykułów »radziecko-prawnych « (sovetsko-pravovyh)" 19 .

Podstawowy zarzut kierowany przez P.I. Stuczkę pod adresem kodeksu cywilnego z 1922 roku nie dotyczył wszelako burżuazyjnej genezy zawartych w nim unormowań, a samego jego zamysłu jako aktu prawnego całościowo regulującego stosunki społeczne o charakterze majątkowym. Odwołując się do słów W.I. Lenina z 1917 roku, P.I. Stuczka przyjmował, że w przejściowym okresie socjalizmu, to jest przed nadejściem komunizmu, prawo burżuazyjne nie zostaje wyeliminowane $\mathrm{z}$ systemu prawa $\mathrm{w}$ całości - o ile traci ono moc $\mathrm{w}$ zakresie regulacji własności środków produkcji (która już w socjalizmie nie może przysługiwać podmiotom prywatnym), o tyle jego obowiązywanie jest dopuszczalne w dziedzinie normowania dystrybucji dóbr i dystrybucji pracy między członkami społeczeństwa ${ }^{20}$. P.I. Stuczka dostrzegał konieczność obowiązywania w prawie radzieckim regulacji cywilnoprawnych, zakorzenionych w prawie burżuazyjnym, z uwagi na realizację Nowej Polityki Ekonomicznej — wskazywał, że Nowa Polityka Ekonomiczna jest „podstawą (bazą), na której funkcjonuje nasze prawo cywilne" 21 . Jako instrument przeciwdziałania nadużywaniu burżuazyjnych w swej istocie przepisów kodeksu cywilnego przez podmioty prywatnego sektora gospodarki, w sposób zagrażający socjalistycznym podstawom ustroju gospodarczego, P.I. Stuczka postrzegał treść art. 1 kodeksu cywilnego, który stanowił, że „prawa cywilne (graždanskie prava) podlegają ochronie prawnej, z wyjątkiem przypadków, gdy są wykonywane w sposób sprzeczny z ich społeczno-gospodarczym przeznaczeniem”22. P.I. Stuczka porównał art. 1 kodeksu cywilnego do „miecza Damoklesa (Damoklov meč) nad Nową Polityką Ekonomiczną i burżuazją"23.

17 P.I. Stučka, Klassovoe gosudarstvo i graždanskoe pravo, Moskwa 1924, s. 54.

18 P.I. Stučka, Socialističeskoe hozâjstvo i sovetskoe pravo, „Revolûciâ prava” 1927, nr 1,

s. 10. Tłum. cytatów - W.M.

19 P.I. Stučka, Kurs..., t. 1, s. 81.

20 P.I. Stučka, Graždanskoe pravo i praktika ego primeneniâ, „Revolûciâ prava” 1929, nr 2, s. 134.

21 Ibidem, s. 135.

22 O znaczeniu art. 1 kodeksu cywilnego z 1922 roku dla stosowania prawa cywilnego zob. K. Sójka-Zielińska, Historia prawa, Warszawa 2009, s. 339.

23 P.I. Stučka, Kurs..., t. 2, s. 249. 
Krytyka kodeksu cywilnego z 1922 roku, jako aktu prawnego o nazbyt szerokim zakresie regulacji, została najpełniej wyrażona przez P.I. Stuczkę w artykule Prawo cywilne i praktyka jego stosowania, opublikowanym w 1929 roku. Autor, mając zasadniczo świadomość potrzeby funkcjonowania unormowań cywilnoprawnych w przejściowym okresie socjalizmu, uznawał, że kodeks cywilny powinien odznaczać się bardzo ograniczonym zakresem regulacji, zamykającym się li tylko $\mathrm{w}$ wąskim kręgu zagadnień pozostających $\mathrm{w}$ sferze oddziaływania prawa burżuazyjnego. W istocie jednak kodeks cywilny z 1922 roku okazał się aktem prawnym o całościowym zakresie regulacji, „obejmującym szerokie masy”, normującym - co do zasady — ogół stosunków majątkowych w społeczeństwie ${ }^{24}$. Co istotne, oddziaływaniem obcego genetycznie i ideologicznie prawa cywilnego zostało objęte także funkcjonowanie socjalistycznego sektora gospodarki. Jakkolwiek do kodeksu zostały wprowadzone przepisy w treści socjalistyczne (jako takie wskazywano między innymi art. 1, 4, 30, 33, 147 i 150), pozostawało to bez wpływu na okoliczność, że podstawową, ogólną regulacją stosunków majątkowych i gospodarczych w państwie radzieckim stał się kodeks cywilny, to jest akt prawny o treści i idei właściwych prawu burżuazyjnemu, a macierzystą gałąz prawa dla tej sfery zagadnień stanowiło prawo cywilne, ujmowane przez P.I. Stuczkę jako „produkt rozwiniętej gospodarki towarowej” i ,charakterystyczna cecha burżuazyjnego, kapitalistycznego społeczeństwa"25.

Zamysł kodeksu cywilnego jako aktu prawnego całościowo regulującego ogół stosunków majątkowych i gospodarczych był zdaniem P.I. Stuczki nieakceptowalny w państwie socjalistycznym i nie odpowiadał realiom funkcjonowania społeczeństwa oraz gospodarki radzieckiej. Krytyka idei kodyfikacji prawa cywilnego została przedstawiona przez P.I. Stuczkę w aspektach de lege lata i de lege ferenda. De lege lata autor zaznaczał, że trzy działy prawa tradycyjnie zaliczane do prawa cywilnego - prawo ziemskie, prawo pracy i prawo rodzinne — zostały objęte odrębnymi kodyfikacjami ${ }^{26}$, a to $\mathrm{z}$ uwagi na wyraźnie odznaczające się w państwie socjalistycznym cechy swoiste ustroju ziemskiego, statusu pracowniczego i społecznej roli rodziny, skutkujące niekompatybilnością radzieckiego prawa ziemskiego, prawa pracy i prawa rodzinnego wobec podstawowych założeń zakorzenionej w prawie burżuazyjnym kodyfikacji cywilnoprawnej ${ }^{27}$. De lege ferenda P.I. Stuczka wskazywał, że pewne instytucje i sfery regulacji prawnej, objęte wprawdzie zasięgiem normowania kodeksu cywilnego, są jednak do niego nieprzystawalne i powinny zostać wyłączone do odrębnego aktu prawnego — odnosiło się to do funkcjonowania socjalistycznego sektora gospodarki oraz instytucji prawnych dotyczących stosunków pozbawionych przymiotu ekwiwalentności,

24 P.I. Stučka, Graždanskoe prawo..., s. 131-132.

25 Ibidem, s. 131, 134.

26 Były to: kodeks ziemski RFSRR z 1922 roku, kodeks pracy RFSRR z 1922 roku oraz kodeks prawa małżeńskiego, rodzinnego i opiekuńczego RFSRR z 1926 roku.

27 P.I. Stučka, Graždanskoe pravo..., s. 136-137. 
którą badacz postrzegał jako cechę znamienną stosunków cywilnoprawnych (były to między innymi stosunki mieszkaniowe, w szczególności pracownicze, renty z tytułu wypadków przyznawane na podstawie przepisów o zabezpieczeniu społecznym oraz przejęcie własności prywatnej przez państwo) ${ }^{28}$. Okoliczności te w 1929 roku skłoniły P.I. Stuczkę do stwierdzenia, że „na naszych oczach umiera przestarzały, wszechobejmujący, burżuazyjny kodeks cywilny i umierałby jeszcze szybciej, gdyby nie znajdował silnego poparcia w burżuazyjnym światopoglądzie prawniczym, panującym jeszcze w znacznym stopniu nad naszą myślą prawniczą"29.

Jak wskazywano, sferą regulacji prawnej, której objęcie oddziaływaniem kodeksu cywilnego przedstawiało się dla P.I. Stuczki jako wątpliwe, było funkcjonowanie socjalistycznego sektora gospodarki, to jest stosunki między tworzącymi ten sektor przedsiębiorstwami państwowymi. Wypada wyraźnie zaznaczyć, że stanowisko P.I. Stuczki w przedmiocie stosowania kodeksu cywilnego do stosunków między przedsiębiorstwami państwowymi w ciągu lat ewoluowało i — wraz z nasilaniem się krytyki kodeksu cywilnego i roli prawa cywilnego w regulacji gospodarki radzieckiej — zmierzało w kierunku rozstrzygnięcia negatywnego. W pierwszym tomie Kursu radzieckiego prawa cywilnego, wydanym w 1927 roku, P.I. Stuczka zaznaczał, że „instytucje państwowe i przedsiębiorstwa państwowe nawet do stosunków między sobą stosują w całości normy kodeksu cywilnego" (,gosučreždeniâ i gospredpriâtiâ daže dlâ snošenii meždu soboû pol'zuûtsâ celikom normami G.K.") ${ }^{30}$. Dwa lata później, w artykule Prawo cywilne i praktyka jego stosowania, zasygnalizował wątpliwości na tle analizowanego zagadnienia: „regulacja wzajemnych stosunków między przedsiębiorstwami państwowymi, opartych na podporządkowaniu i planowości, stopniowo wyłącza się spod zakresu obowiązywania kodeksu cywilnego” („regulirovanie vzaimootnošenij gospredpriâtij, v porâdke podčineniâ i planovosti, postepenno uhodit iz-pod dejstviâ GK”), w konsekwencji „stosowanie norm kodeksu cywilnego często jest już sporne” (,primenenie norm GK často uže sporno”), a ponadto „rysuje się tutaj nowy dział prawa — normy gospodarczo-administracyjne” („tut namečaetsâ poka novyj otdel prava — hozâjstvenno-administrativnye normy") ${ }^{31}$. W 1931 roku, w trzecim tomie Kursu radzieckiego prawa cywilnego, P.I. Stuczka oznajmia już stanowczo, że „nadchodzi czas, gdy z prawa administracyjnego w ogólności powinno wyodrębnić się specjalne prawo gospodarczo-administracyjne” (,nastupaet vremâ, kogda iz ètogo administrativnogo prava voobŝe dolžno vydelit'sâ osoboe hozâjstvenno-administrativnoe pravo”), regulujące „sektor

\footnotetext{
28 Ibidem, s. 137.

29 Ibidem.

30 P.I. Stučka, Kurs..., t. 1, s. 104.

31 P.I. Stučka, Graždanskoe pravo..., s. 137.
} 
socjalistyczny” (,socialističeskij sektor”), przeciwstawiany „sektorowi kapitału prywatnego" (,sektor častnogo kapitala") ${ }^{32}$.

Z pełnym przekonaniem należy zatem stwierdzić, że wyróżnienie prawa gospodarczo-administracyjnego, odnoszonego do funkcjonowania jednego $\mathrm{z}$ dwóch sektorów gospodarki radzieckiej, nastąpiło w konsekwencji prowadzonych przez P.I. Stuczkę ogólnych analiz i rozważań dotyczących zakresu regulacji kodeksu cywilnego RFSRR z 1922 roku oraz roli prawa cywilnego jako instrumentu regulacji stosunków majątkowych i gospodarczych ${ }^{33}$. Istotą wyodrębnienia prawa gospodarczo-administracyjnego było wyłączenie wiodącego i dominującego sektora gospodarki socjalistycznej (państwowej) z nazbyt rozległego - według P.I. Stuczki — zakresu oddziaływania kodeksu cywilnego jako aktu prawnego o proweniencji burżuazyjnej.

\section{III}

Jakkolwiek nazwisko P.I. Stuczki jest współcześnie identyfikowane z wyróżnieniem prawa gospodarczo-administracyjnego w przeciwstawieniu do prawa cywilnego, warto zaznaczyć, że początkowo uczony ten opowiadał się za utożsamianiem pojęć „prawo gospodarcze” i ,prawo cywilne”. W 1924 roku P.I. Stuczka wskazywał, że główną funkcją radzieckiego ustawodawstwa cywilnego jest regulacja działalności gospodarczej, w ramach której funkcjonuje złożony, lecz wspólny system organizacji produkcji i kształtujących się w jej ramach stosunków społecznych - gałęzią prawa regulującą te stosunki jest zaś „wspólne radzieckie prawo cywilne lub gospodarcze” („edinoe sovetskoe graždanskoe ili hozâjstvennoe pravo") ${ }^{34}$.

Myśl P.I. Stuczki o rozróżnieniu prawa gospodarczo-administracyjnego i prawa cywilnego uwarunkowana była stwierdzeniem zasadniczych różnic w funkcjonowaniu dwóch sektorów gospodarki radzieckiej, które ukształtowały się w okresie Nowej Polityki Ekonomicznej — sektora socjalistycznego (obejmującego przede wszystkim przedsiębiorstwa państwowe) i sektora prywatnego (obejmującego prywatne podmioty działalności gospodarczej). Cechami znamiennymi sektora socjalistycznego były planowość i zorganizowanie - sektor ten koncentrował się wokół „zorganizowanego centrum socjalistycznej dyktatury proletariatu”, jakim była „władza radziecka, która na podstawie państwowej własności socjalistycznej zarządza ogromnym socjalistycznym sektorem stosunków"35. Sektor prywatny

32 P.I. Stučka, Kurs..., t. 3, s. 5-6, 9.

33 Zob. I.V. Eršova, L.V. Andreeva, Istoriâ rossijskogo predprinimatel'skogo (hozâjstvennogo) $i$ kommerčeskogo (torgovogo) prava, „Vestnik Universiteta imeni O.E. Kutafina (MGÛA)” 2015, nr 1, s. 30.

34 P.I. Stučka, Klassovoe gosudarstvo..., s. 55.

35 P.I. Stučka, Kurs..., t. 3, s. 5. 
odznaczał się natomiast charakterem anarchicznym i panującą w nim wolnością konkurencji ${ }^{36}$. Między oboma sektorami toczyła się walka, scharakteryzowana przez P.I. Stuczkę Leninowskim zawołaniem: „kto kogo?”37. P.I. Stuczka zaznaczał, że walka ta jest nieodwracalnie rozstrzygnięta na korzyść — co oczywiste sektora socjalistycznego ${ }^{38}$.

Mając na względzie zasadnicze różnice w materii stosunków kształtujących się w sektorze socjalistycznym (bazujących na planowości) i sektorze prywatnym (bazujących na anarchii), autor wskazywał, że różnice te powinny znajdować odzwierciedlenie także $\mathrm{w}$ formie prawnej regulacji funkcjonowania obu sektorów, co powinno prowadzić do sytuacji, w której forma prawna dla „regulowania stosunków sektora socjalistycznego ma zupełnie inny kształt albo przynajmniej inny charakter" ${ }^{\prime 3}$. Dla regulacji funkcjonowania zorganizowanego (ustrukturyzowanego) sektora socjalistycznego nieadekwatne były regulacje cywilnoprawne, oparte na paradygmacie stosunków między podmiotami samodzielnymi i autonomicznymi, przybierających charakter horyzontalny. Prawo normujące sektor socjalistyczny winno mieć charakter prawa gospodarczo-administracyjnego, którego administracyjne znamię odnosiłoby się do roli organów państwowych — w państwie socjalistycznym bowiem ,rola tzw. działalności wykonawczej organów państwowych coraz bardziej przekształca się w zarządzanie gospodarcze władzy państwowej” ${ }^{40}$. Stanowisko to nawiązywało do poglądów W.I. Lenina na rolę administracji w państwie socjalistycznym - w 1918 roku W.I. Lenin zaznaczał, że „rosnąć, rozwijać się i krzepnąć” będzie aparat państwowy zarządzający gospodarką, natomiast aparatowi administracyjnemu rozumianemu wąsko, pozbawionemu zadań związanych z zarządzaniem gospodarką, typowemu dla „starych państw” (,apparatu starogo gosudarstva”), przyjdzie obumrzeć ${ }^{41}$. Regulacja stosunku prawa do gospodarki wyraźnie odróżniała prawo socjalistyczne od prawa burżuazyjnego - o ile prawo burżuazyjne dążyło do rozdzielenia prawa i gospodarki, o tyle w prawie socjalistycznym dostrzegalna jest rosnąca „więź

${ }^{36}$ Ibidem, s. 10.

37 Na II Wszechrosyjskim Zjeździe Politproswietów (jednostek edukacji politycznej) w październiku 1921 roku W.I. Lenin wskazał, że między kapitalizmem i socjalizmem toczy się walka pod hasłem: „kto kogo wyprzedzi?” (kto kogo operedit?) — A. Fesenko, T. Fesenko, Russkij âzyk pri sovetah, Nowy Jork 1955, s. 179.

38 P.I. Stučka, Kurs..., t. 3, s. 5.

39 Ibidem, s. 10.

40 Ibidem.

41 V.I. Lenin, Polnoe sobranie sočinenij, t. 36, Moskwa 1974, s. 377-378. Rozwijając myśl W.I. Lenina, administratywista S.M. Biercynski wskazywał, że w państwie socjalistycznym władza państwowa wykonuje głównie zadania „regulacyjno-pozytywne” (regulâtivno-položitel'nye), polegające na zarządzaniu gospodarką, życiem społeczno-kulturalnym oraz obronnością, w odróżnieniu od burżuazyjnej władzy państwowej, której działalność ogranicza się przede wszystkim do sfery policyjnej — idem, Predmet sovetskogo administrativnogo prava i metod ego izučeniâ, „Problemy socialističeskogo prava" 1939 , nr 2, s. 66-67. 
prawa i gospodarki” („svâz' hozâjstva i prava”) ${ }^{42}$. Uzasadniając wyróżnienie prawa gospodarczo-administracyjnego, P.I. Stuczka wskazywał, że w dyktaturze proletariatu więź prawa i gospodarki odzwierciedla „zorganizowaną celowość" („organizovannaâ celesoobraznost"'), realizowaną w formie regulacji dyrektywnych lub normalizujących, zasad ustawowych lub równoważnych im rozporządzeń rządowych ${ }^{43}$.

P.I. Stuczka proponował, by normy regulujące funkcjonowanie socjalistycznego sektora gospodarki zostały ujęte w kodeksie, którego tytuł - zgodnie ze sformułowaną przez niego sugestią (co wyraźnie podkreślił) — brzmiałby: „kodeks gospodarczo-administracyjny” („hozâjstvenno-administrativnyj”) ${ }^{44}$. P.I. Stuczka zaznaczał, że myśl o wyodrębnieniu prawnej regulacji sektora socjalistycznego jest „stosunkowo nowa”, przy czym wypada nadmienić, iż postulat stworzenia autonomicznego reżimu prawnego dla tego sektora, oddzielonego od regulacji funkcjonowania sektora prywatnego zawartej w kodeksie cywilnym, przed P.I. Stuczką sformułowali P.A. Liebiediew i S.M. Pruticki ${ }^{45}$. Normy prawa gospodarczo-administracyjnego przybierałyby zasadniczo charakter norm imperatywnych, na podstawie których organy państwowe wykonywałyby zadania z zakresu zarządzania gospodarką, w sposób władczy określając funkcjonowanie jednostek sektora socjalistycznego ${ }^{46}$. Przez wzgląd na powyższe w prawnej regulacji sektora socjalistycznego zbędnym instrumentem stałaby się umowa, stanowiąca instytucję charakterystyczną dla sektora prywatnego - w sektorze socjalistycznym zastąpiłyby ją ,plan i władcza regulacja" 47 . Z perspektywy treściowej unormowania zawarte w kodeksie gospodarczo-administracyjnym układałyby się w dwie podstawowe grupy — „reguły i regulaminy techniczne” („tehničeskie pravila i predpisaniâ") oraz „reguły wewnętrznego funkcjonowania” (,pravila vnutrennego regulirovaniâ") ${ }^{48}$. Reguły wewnętrznego funkcjonowania znalazłyby odzwierciedlenie przede wszystkim w postaci unormowań określających wewnętrzną organizację i działalność jednostek sektora socjalistycznego - P.I. Stuczka przewidywał, że załącznikami do kodeksu mogłyby stać się standardowe statuty tych jednostek, które zastąpiłyby dotychczas obowiązujące odrębne statuty poszczególnych jednostek, prowadząc do ujednolicenia zasad ich wewnętrznego funkcjonowania ${ }^{49}$.

42 P.I. Stučka, Kurs..., t. 3, s. 9.

43 Ibidem.

44 Ibidem.

45 P.A. Lebedev, Graždanskij kodeks i gosudarstvennoe hozâjstvo, „Vestnik Verhovnogo suda SSSR" 1927, nr 2, s. 13; S.M. Prutickij, Hozâjstvennaâ politika i hozâjstvennoe pravo za desât' let, „Eženedel'nik sovetskoj ûsticii” 1928, nr 9, s. 279.

46 P.I. Stučka, Kurs..., t. 3, s. 10.

47 P.I. Stučka, G.N. Amfiteatrov, Osnovy graždanskogo zakonodatel'stva SSSR, Moskwa 1931, s. 5.

48 P.I. Stučka, Kurs..., t. 3, s. 8.

49 Ibidem, s. 11. 
Obraz prawa gospodarczo-administracyjnego skodyfikowanego w kodeksie gospodarczo-administracyjnym był obrazem modelowym sformułowanym w ramach autorskiej koncepcji P.I. Stuczki i nie znalazł odzwierciedlenia na gruncie prawa pozytywnego. Wypada wszakże zaznaczyć, że postulat wyodrębnienia prawa gospodarczo-administracyjnego spotkał się z pewnym uznaniem - w 1929 roku VI Zjazd Pracowników Wymiaru Sprawiedliwości z inicjatywy P.I. Stuczki podjął uchwałę, w której stwierdzono, że „ze wzglądu na rosnące rozmiary wewnątrzorganizacyjnej regulacji produkcji i obrotu w socjalistycznym sektorze gospodarki konieczne jest wyłączenie tych zagadnień ze sfery prawa i procedury cywilnej przez wydzielenie ich do specjalnego prawa gospodarczo-administracyjnego"; w tymże roku na Moskiewskim Uniwersytecie Państwowym utworzono Katedrę Prawa Gospodarczo-Administracyjnego ${ }^{50}$.

De lege lata P.I. Stuczka wskazywał, że prawo gospodarczo-administracyjne znajduje się wszelako w stadium formowania, a podział prawa gospodarczo-administracyjnego i prawa cywilnego ma charakter płynny. Było to związane zasadniczo z okolicznością, że regulacja funkcjonowania sektora socjalistycznego odbywa się ,jeszcze” w ramach cywilnoprawnej formy (,regulirovanie osuŝestvlâetsâ eŝe v graždansko-pravovoj forme") ${ }^{51}$. Okoliczność ta utrudniała $\mathrm{w}$ istotnym stopniu stosowanie prawa, przede wszystkim w związku z koniecznością rozstrzygania, czy stosunki powstające na tle umów zawieranych przez jednostki sektora socjalistycznego podlegają jurysdykcji cywilnoprawnej.

Mając na względzie, że - wobec braku (de lege lata) odrębnego reżimu prawnego dla sektora socjalistycznego - do jego funkcjonowania znajdują zastosowanie instrumenty cywilnoprawne, P.I. Stuczka stanowczo akcentował konieczność stosowania cywilnoprawnej (burżuazyjnej) „formy” z uwzględnieniem socjalistycznej „,treści”. W swoich pracach wielokrotnie krytykował formalistyczne podejście do prawa, wyrażające się w przedkładaniu formy nad treść - za zjawisko niepożądane i niebezpieczne uznawał charakterystyczną dla prawników burżuazyjnych „wiarę w gołą normę prawną” oraz „fetyszyzm ustawy i umowy" ${ }^{2}$, który w skrajnych przypadkach mógł przerodzić się w ,idololatrię (idolopoklonstvo) wobec litery prawa"53.

Wartym zaznaczenia zagadnieniem wydaje się stosunek koncepcji P.I. Stuczki do tak zwanej wymiennej koncepcji prawa (,»menovaâ« koncepciâ prava"), sformułowanej przez J.B. Paszukanisa, która istotnie wpłynęła na radziecką naukę prawa lat dwudziestych i trzydziestych. Zgodnie z koncepcją wymienną forma prawna osiąga swój kulminacyjny punkt w społeczeństwie burżuazyjno-kapitalistycznym, w związku z czym prawo burżuazyjne jest najbardziej

\footnotetext{
50 È.V. Talapina, Publičnoe pravo i èkonomika, Moskwa 2011, s. 23-24.

51 P.I. Stučka, Kurs..., t. 3, s. 11.

52 P.I. Stučka, Graždanskoe pravo..., s. 133.

53 P.I. Stučka, Kurs..., t. 1, s. 107.
} 
rozwiniętym systemem prawa ${ }^{54}$. Wynika to z okoliczności, że gospodarka kapitalistyczna opiera się na obrocie towarowo-pieniężnym, w którym stosunki nawiązują się między samodzielnymi i autonomicznymi podmiotami prywatnymi, a instrumentem nawiązywania tych stosunków jest przede wszystkim umowa. Istnienie i funkcjonowanie w obrocie prywatnego podmiotu gospodarczego uwarunkowane jest posiadaniem przez niego zdolności prawnej, której źródłem jest norma prawna ${ }^{55}$. Również doniosłość prawna konstrukcji umowy materializuje się na gruncie regulujących ją norm prawnych — umowa, jako podstawowy środek nawiązywania stosunków w gospodarce towarowo-pieniężnej, była według J.B. Paszukanisa centralną instytucją prawa ${ }^{56}$. Funkcjonowanie stosunków gospodarczych $\mathrm{w}$ obrocie towarowo-pieniężnym było więc warunkowane normami prawnymi regulującymi zdolność (podmiotowość) prawną oraz znaczenie prawne umowy - prawo przedstawiało się tu jako normatywne wyrażenie stosunków między niezależnymi i równymi sobie podmiotami ${ }^{57}$. Niepomiernie mniejszą rolę należy natomiast przypisać prawu w systemie gospodarki socjalistycznej, w której stosunki gospodarcze pozbawione są charakteru towarowo-pieniężnego. Stosunki te, kształtujące się wewnątrz struktur gospodarki zarządzanej centralnie — pomiędzy jednostkami nieodznaczającymi się znamieniem samodzielności — przybierają charakter stosunków nie prawnych, lecz organizacyjnych. Ścisła forma prawna jest dla tych stosunków zbędna, wobec czego wraz z rozwojem gospodarki socjalistycznej ma następować „całkowite wywiewanie nadbudowy prawnej” (,vyvetrivanie samoj ûridičeskoj nadstrojki v celom”) ${ }^{58}$.

W jaki sposób przedstawia się zatem koncepcja P.I. Stuczki na tle wymiennej teorii prawa J.B. Paszukanisa? Według I.A. Isajewa wymienna teoria prawa stała się podstawą wyróżnienia w strukturze prawnej gospodarki radzieckiej dwóch sektorów - sektora socjalistycznego, opartego na planowości, obejmującego regulacje organizacyjno-techniczne, oraz sektora „prywatno-gospodarczego" (,častno-hozâjstvennyj"), w którym pełne zastosowanie znajdują normy prywatnoprawne ${ }^{59}$. W rzeczy samej P.I. Stuczka, rozróżniając prawne reżimy funkcjonowania dwóch sektorów gospodarki radzieckiej, zaznaczał, że w skodyfikowanym prawie gospodarczo-administracyjnym, regulującym sektor socjalistyczny, będą zawierać się unormowania o charakterze technicznym oraz dotyczące wewnętrznej organizacji jednostek gospodarki socjalistycznej ${ }^{60}$, co zdaje się korespondować z koncepcją J.B. Paszukanisa. Mimo tego podobieństwa jako fundamentalnie niezgodne $\mathrm{z}$ teo-

54 E.E. Protopopov, Menovaâ teoriâ prava, „Aktual'nye problemy rossijskogo prava” 2015, nr 1, s. 21.

55 E.B. Pašukanis, Obŝâa teoriâ prava i marksizm, Moskwa 1927, s. 53.

56 Ibidem, s. 82.

57 E.E. Protopopov, op. cit., s. 21.

58 E.B. Pašukanis, op. cit., s. 96.

59 I.A. Isaev, Hozâjstvennoe pravo v sisteme sovetskoj ûridičeskoj nauki 20-h godov, „Sovetskoe gosudarstvo i pravo" 1982, nr 2, s. 107.

${ }^{60}$ P.I. Stučka, Kurs..., t. 3, s. 8. 
rią wymienną przedstawia się stanowisko P.I. Stuczki w przedmiocie „prawnego" charakteru prawa gospodarczo-administracyjnego. Zgodnie z wymienną koncepcją prawa prawo gospodarczo-administracyjne powinno - jak wskazywał S.N. Bratuś — przekształcać się w „nie-prawo, w naukę o organizacyjnej strukturze gospodarki socjalistycznej" 1 . P.I. Stuczka nie odmawiał natomiast charakteru prawa unormowaniom prawa gospodarczo-administracyjnego, uznając, że powinny być one ujęte w akcie prawnym - kodeksie, nie zaś w formie tez naukowych. Co więcej, w odróżnieniu od J.B. Paszukanisa P.I. Stuczka twierdził, że wraz z rozwojem gospodarki socjalistycznej rola prawa nie będzie maleć, lecz rosnąć. Wskazywał bowiem, że rozwój ten prowadzi do zacieśniania się „więzi gospodarki i prawa” („,svâz' hozâjstva i prava"), przede wszystkim przez zwiększanie się aktywności państwowych organów zarządzania gospodarką w dziedzinie tworzenia i stosowania norm prawnych regulujących zarządzanie gospodarką ${ }^{62}$.

\section{IV}

Na gruncie przedstawionych analiz i rozważań nie budzi wątpliwości, że prawo gospodarczo-administracyjne w ujęciu P.I. Stuczki należy postrzegać jako teoretyczną koncepcję modelowego obrazu pewnego zbioru unormowań, której przyszłe odzwierciedlenie w sferze prawa pozytywnego badacz ten uznawał za pożądane i celowe. Odzwierciedlenie to powinno przybrać postać kodeksu gospodarczo-administracyjnego, który zawierałby normy całościowo regulujące funkcjonowanie socjalistycznego sektora gospodarki radzieckiej. Normy te, zarówno w perspektywie formalnej, jak i treściowej, fundamentalnie odróżniałyby się od unormowań cywilnoprawnych, de lege lata oddziałujących na działalność jednostek sektora socjalistycznego. Koncepcja prawa gospodarczo-administracyjnego bezsprzecznie nie stanowiła opisu obowiązujących ówcześnie regulacji prawnych — jakkolwiek P.I. Stuczka zwracał uwagę na wyodrębnienie się w systemie prawa grupy „norm gospodarczo-administracyjnych” (,hozâjstvenno-administrativnye normy"), normy te de lege lata nie formowały samodzielnej gałęzi prawa ${ }^{63}$. Koncepcji prawa gospodarczo-administracyjnego należy zatem przypisać charakter postulatywny, nie zaś deskryptywny.

Leżąca u podstaw koncepcji prawa gospodarczo-administracyjnego P.I. Stuczki idea wydzielenia z prawa cywilnego odrębnej gałęzi prawa regulującej funkcjonowanie systemu gospodarki socjalistycznej nie została inkorporowana do ustawodawstwa radzieckiego, w którym aż do rozpadu ZSRR zachowano zasadę

61 S.N. Bratus', K probleme hozâjstvenno-administrativnogo prava, „Sovetskoe gosudarstvo i revolûciâ prava" 1930, nr 11-12, s. 37.

62 P.I. Stučka, Kurs..., t. 3, s. 9.

63 P.I. Stučka, Graždanskoe pravo..., s. 137. 
jedności prawa cywilnego ${ }^{64}$. Choć koncepcja P.I. Stuczki ukształtowała się pod wpływem Nowej Polityki Ekonomicznej, której realizacja została zakończona w 1929 roku $^{65}$, odniesienia do tej teorii wielokrotnie pojawiały się w późniejszych rozważaniach uczonych radzieckich nad zasadnością wyodrębniania prawa gospodarczego jako gałęzi prawa. Teoretyczna doniosłość idei P.I. Stuczki zdaje się bowiem wyrażać w okoliczności, że była ona pierwszą koncepcją dowodzącą, że problem antynomii: jedność prawa cywilnego lub wydzielenie z niego gałęzi prawa obejmującej normy regulujące działalność gospodarczą, analizowany dotychczas w systemach opartych na gospodarce kapitalistycznej, może być aktualny również na gruncie gospodarki socjalistycznej.

\section{Bibliografia}

Bercinskij S.M., Predmet sovetskogo administrativnogo prava i metod ego izučeniâ, „Problemy socialističeskogo prava" 1939, $\mathrm{nr} 2$.

Bosiacki A., Utopia, władza, prawo. Doktryna i koncepcje prawne „bolszewickiej” Rosji 19171921, Warszawa 1999.

Bratus' S.N., K probleme hozâjstvenno-administrativnogo prava, „Sovetskoe gosudarstvo i revolûciâ prava" 1930, nr 11-12.

Eršova I.V., Andreeva L.V., Istoriâ rossijskogo predprinimatel'skogo (hozâjstvennogo) i kommerčeskogo (torgovogo) prava, „Vestnik Universiteta imeni O.E. Kutafina (MGÛA)” 2015, nr 1.

Fesenko A., Fesenko T., Russkij âzyk pri sovetah, Nowy Jork 1955.

Giaro T., Prawo handlowe czy gospodarcze? Kilka modeli historycznych, [w:] Prawo handlowe XXI wieku. Czas stabilizacji, ewolucji czy rewolucji. Księga jubileuszowa Profesora Józefa Okolskiego, red. M. Modrzejewska, Warszawa 2010.

Gincburg L.Â., K voprosu o hozâjstvennom prave, „Sovetskoe gosudarstvo i prawo” 1956, nr 8.

Gojhbarg A.G., Hozâjstvennoe pravo RSFSR, t. 1. Graždanskij kodeks, Moskwa-Leningrad 1923.

Ioffe O.S., Izbrannye trudy po graždanskomu pravu. Iz istorii civilističeskoj mysli. Graždanskoe pravootnošenie. Kritika teorii , hozâjstvennogo prava”, Moskwa 2000.

Isaev I.A., Hozâjstvennoe pravo v sisteme sovetskoj ûridičeskoj nauki 20-h godov, „Sovetskoe gosudarstvo i pravo" 1982, $\mathrm{nr} 2$.

Lebedev P.A., Graždanskij kodeks i gosudarstvennoe hozâjstvo, „Vestnik Verhovnogo suda SSSR” $1927, \mathrm{nr} 2$.

Lenin V.I., Polnoe sobranie sočinenij, t. 36, Moskwa 1974.

Lityński A., Prawo Rosji i ZSRR 1917-1991, czyli historia wszechzwiązkowego komunistycznego prawa (bolszewików). Krótki kurs, Warszawa 2017.

Małecki W., Dyskusja nad koncepcja prawa gospodarczego w nauce radzieckiej w latach 19561958, „Krakowskie Studia z Historii Państwa i Prawa” 2016, nr 9, z. 3.

Mamutov V.K., Hozâjstvennoe pravo (Ukrainy), Kijów 2002.

Marples D., Historia ZSRR, Wrocław 2006.

${ }^{64}$ A. Lityński, op. cit., s. 268.

65 T. Giaro słusznie zauważa, że koncepcja prawa gospodarczego P.I. Stuczki została sformułowana na schyłkowym etapie Nowej Polityki Ekonomicznej - idem, Prawo handlowe czy gospodarcze? Kilka modeli historycznych, [w:] Prawo handlowe XXI wieku. Czas stabilizacji, ewolucji czy rewolucji. Księga jubileuszowa Profesora Józefa Okolskiego, red. M. Modrzejewska, Warszawa 2010, s. 179.

Studia nad Autorytaryzmem i Totalitaryzmem 42, nr 2, 2020

(C) for this edition by CNS 
Pašukanis E.B., Obŝâ̂ teoriâ prava i marksizm, Moskwa 1927.

Pavlov I.V., O sisteme sovetskogo socialističeskogo prava, „Sovetskoe gosudarstvo i prawo” 1958 , nr 11 .

Protopopov E.E., Menovaâ teoriâ prava, „Aktual'nye problemy rossijskogo prava” 2015, nr 1.

Prutickij S.M., Hozâjstvennaâ politika i hozâjstvennoe pravo za desât' let, „Eženedel'nik sovetskoj ûsticii”" 1928, nr 9.

Rot H., Jedność i podziały systemu prawa socjalistycznego, Wrocław 1971.

Sójka-Zielińska K., Historia prawa, Warszawa 2009.

Stučka P.I., Graždanskoe pravo i praktika ego primeneniâ, „Revolûciâ prava” 1929, nr 2.

Stučka P.I., Klassovoe gosudarstvo i graždanskoe pravo, Moskwa 1924.

Stučka P.I., Kurs sovetskogo graždanskogo prava, t. 1. Vvedenie v teoriû graždanskogo prava, Moskwa 1927.

Stučka P.I., Kurs sovetskogo graždanskogo prava, t. 2. Obŝâ čast' graždanskogo prava, Moskwa 1929.

Stučka P.I., Kurs sovetskogo graždanskogo prava, t. 3. Osobennaâ čast' graždanskogo prava, Moskwa-Leningrad 1931.

Stučka P.I., Socialističeskoe hozâjstvo i sovetskoe pravo, „Revolûciâ prava” 1927, nr 1.

Stučka P.I., Amfiteatrov G.N., Osnovy graždanskogo zakonodatel'stva SSSR, Moskwa 1931.

Šargorodskij M.D., Ioffe O.S., O sisteme sovetskogo prava, „Sovetskoe gosudarstvo i prawo” 1957, nr 6.

Šreter V.N., Sovetskoe hozâjstvennoe prawo, Moskwa-Leningrad 1928.

Tadevosân V.S., Nekotorye voprosy sistemy sovetskogo prava, „Sovetskoe gosudarstvo i prawo” 1956, $\mathrm{nr} 9$.

Talapina Ė.V., Publičnoe pravo i èkonomika, Moskwa 2011.

Vyšinskij A.Â., XVIII s"ezd VKP(b) i zadači nauki socialističeskogo prava, „Sovetskoe gosudarstvo i prawo" 1939 , nr 3.

Włodyka S., Problem ,prawa gospodarczego”, „Studia Cywilistyczne” 5, 1964.

Zvâgincev A.G., Orlov Û.G., Neizvestnaâ Femida. Dokumenty, sobytiâ, lûdi, Moskwa 2003. 